\title{
Usaha Peningkatan Pemahaman Siswa dan Mahasiswa dalam Masa Pandemi Covid-19 dengan Video Pembelajaran Menggunakan Aplikasi Kinemaster
}

\author{
Yulia Retno Sari ${ }^{1 *}$, Deby Erdriani ${ }^{2}$ \\ 1,2 Fakultas Ilmu Komputer, Universitas Putra Indonesia YPTK Padang, Raya Lubuk Begalung \\ Padang, Sumatera Barat, Indonesia. \\ Corresponding Email: yuliaretnosari2012@gmail.com ${ }^{1 *}$.
}

\section{Article History: \\ Received: Dec 31th 2021 \\ Revised: Jan 05th 2022 \\ Accepted: Jan 11th 2022 \\ Published: Jan 28th 2022}

Keywords: Covid-19; Teaching Videos; Kinemaster; Community Service.

\begin{abstract}
Community Service Activities were carried out online with the theme "Creating Cool Learning Videos to Improve Students' Understanding during the Covid-19 Pandemic". This Community Service partnered with teachers and lecturers in the city of Padang. The purpose of carrying out community service activities is to increase teacher knowledge about teaching video maker applications and teachers are able to make interesting teaching videos so that students are motivated to learn and quickly understand the material being taught. The method used is descriptive qualitative. The data used are primary data from webinar participants. From the results of the implementation of community service activities, it can be concluded that this webinar can increase the knowledge of teachers in the city of Padang in presenting teaching materials. And also improve the ability of teachers in making interesting teaching videos using Kinemaster, this is indicated by a graph of the survey evaluation results of $100 \%$.
\end{abstract}




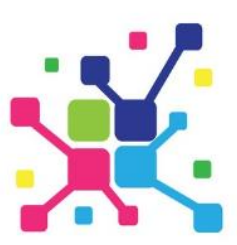

\section{Pendahuluan}

Pandemi Covid-19 melanda Indonesia sejak Maret 2019 berdampak pada berbagai aspek kehidupan Indonesia. Mulai dari bidang pendidikan sampai bidang ekonomi. Dan kebijakan pemerintah dibidang pendidikan, salah satunya adalah dengan belajar online. Pemerintah Indonesia menerbitkan status darurat bencana yang dimulai sejak tanggal 29 Februari sampai 29 Mei 2020 karena penyebaran covid-19 yang sangat tinggi di Indonesia [1]. Sehingga kebijakan bidang pendidikan didasari oleh kebijakan di atas. Menteri Pendidikan dan Kebudayaan Nomor 36962/MPK.A/HK/2020 tanggal 17 Maret 2020 tentang Pembelajaran secara Daring dan Bekerja dari rumah dalam Rangka Pencegahan Penyebaran Corona Virus Disease (Covid-19) [2] . Selanjutnya peraturan tersebut menjadi landasan Surat Edaran Direktorat Jenderal Pendidikan Tinggi Nomor 302/E.E2/KR/2020 tertanggal 31 Maret 2020 tentang Masa Belajar Penyelenggaraan Program Pendidikan yang berbunyi seluruh Pimpinan Perguruasn Tinggi dapat memantau dan membantu kelancaran mahasiswa dalam melakukan pembelajaran dari rumah [3].

Karena aktivitas diluar rumah dibatasin akibat dari pandemi ini, tentu pekerjaan yang dapat dilakukan pun sangat terbatas. Untuk pembelajaran online memerlukan trik agar siswa atau mahasiswa paham akan materi yang diajarkan. Sudah lebih 3 semester berjalan, sangat banyak usaha dan upaya pengajar untuk meningkatkan pemahaman siswa atau mahasiswa dalam memahami materi. Baru-baru ini dalam sebuah penelitian yang melibatkan mahasiswa dinyatakan bahwa yang membuat mahasiswa tersebut paham dan mengerti materi pembelajaran online adalah dengan memberikan video yang berisikan materi dan pembahasan.

Merujuk dari penelitian di atas, pengajar berusaha untuk memberikan materi ajar dalam bentuk video. Video yang diberikan diharapkan menarik dan menyajikan bahan ajar yang mampu membuat mahasiswa paham materi pembelajaran tersebut. Video yang disajikan pada pembelajaran online adalah berbasis digital seperti edit foto jadi video, cara dapatkan video animasi bergerak dan cara buat video animasi keren dengan memggunakan software yang ada di Play Store Android. Video pembelajaran merupakan media yang menyajikan audio dan visual yang berisi pesan-pesan pembelajaran yang berisi konsep, prinsip, prosedur, teori aplikasi pengetahuan untuk membantu pemahaman terhadap suatu materi pembelajaran. Guna menghasilkan video pembelajaran yang mampu meningkatkan motivasi dan efektifitas penggunanya maka pengembangan video pembelajaran harus memperhatikan karakteristik dan kriteria yaitu, antara lain [4] :

a. Clarity of Massage (kejelasan pesan)

Dengan video pembelajaran peserta didik mampu memahami pesan pembelajaran secara lebih bermakna dan informasi dapat diterima secara utuh sehingga dengan sendirinya informasi akan tersimpan dalam memori jangka panjang dan bersifat retensi. 


\section{b. Stand Alone (berdiri sendiri)}

Video pembelajaran yang dikembangkan tidak tergantung pada bahan ajar lain atau tidak harus digunakan bersama-sama dengan bahan ajar lain.

c. User Friendly (bersahabat/akrab dengan pemakainya)

Video pembelajaran menggunakan bahasa yang sederhana, mudah dimengerti dan menggunakan bahasa yang umum. Paparan informasi yang tampil bersifat membantu dan bersahabat dengan pemakainnya, termasuk kemudahan pemakai dalam merespon, mengakses sesuai dengan keinginan.

d. Representasi Isi

Materi harus benar-benar representatif, misalnya materi simulasi atau demonstrasi. Pada dasarnya materi pelajaran baik sosial maupun sains dapat dibuat menjadi media video.

e. Visualisasi dengan media.

Materi dikemas secara multimedia terdapat didalammya teks, animasi, sound, dan video sesuai tuntutan materi. Materi-materi yang digunakan bersifat aplikatif, berproses, dan memiliki tingkat akurasi yang tinggi.

f. Menggunakan kualitas resolusi yang tinggi.

Tampilan berupa grafis media video dibuat dengan teknologi rekayasa digital dengan resolusi tinggi tetapi support untuk setiap spech sistem komputer.

Karena hal-hal diatas kami tim Pengabdian Kepada Masyarakat UPI YPTK Padang melakukan pelatihan dengan tema : "Membuat Video Pembelajaran Keren untuk Meningkatkan Pemahaman Siswa dan Mahasiswa dalam Masa Pandemi Covid-19". Tujuan dalam Pengabdian kepada Masyarakat ini adalah menambah wawasan pengajar dalam penyajian bahan ajar yang menarik sehingga siswa dan mahasiswa lebih cepat memahami materi yang disajikan dalam kelas online selama pandemi ini. Berkaitan dengan situasi di atas, maka dapat dirumuskan masalah-masalah yang dihadapi sebagai berikut: 1) Bagaimana cara memotivasi siswa dan mahasiswa untuk selalu semangat belajar walaupun dirumah semasa Covid-19 ini?, 2) Bagaimana cara mengedit foto jadi video untuk menyajikan video bahan ajar bagi siswa dan mahasiswa ?, 3) Bagaimana cara membuat video animasi bahan ajar untuk menyajikan video bahan ajar bagi siswa dan mahasiswa?.

Pengabdian kepada Masyarakat kali ini, kami tim PKM UPI YPTK Padang memberikan webinar tentang cara editing foto menjadi video dan cara pembuatan video animasi bahan ajar dengan menggunakan aplikasi kinemaster, sehingga diharapkan dengan video tersebut siswa dan mahasiswa mampu memahami materi yang disajikan oleh guru dan dosennya pada kelas online.

Mitra pada Pengabdian kepada Masyarakat ini adalah beberapa guru dan dosen di kota Padang, dan tujuan yang diharapkan pada Pengabdian kepada masyarakat adalah: 1) Guru dan Dosen mampu memberikan motivasi kepada siswa dan mahasiswa 


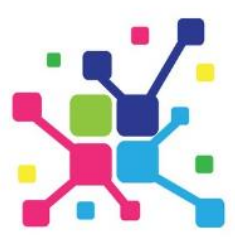

untuk tetap semangat belajar walaupun di rumah saja. 2) Guru dan dosen mampu memahami dan melakukan editing foto menjadi video pada bahan ajar dengan menggunakan kinemaster, 3) Guru dan dosen mampu memahami dan melakukan pembuatan video animasi untuk bahan ajarnya dengan menggunakan kinemaster.

\section{Metode}

a. Metode Pelaksanaan Kegiatan

Dalam pelaksanaan kegiatan ini subjek yang dipilih adalah beberapa guru dan dosen di kota Padang. Langkah-langkah yang dilakukan adalah sebagai berikut [5]:

1) Melakukan rapat koordinasi bersama Tim Pengabdian kepada Masyarakat (PKM) Mandiri Universitas Putra Indonesia YPTK Padang dalam waktu yang terukur dan tersistem.

2) Memilih tema dan kebijakan-kebijakan penting terkait bentuk kegiatan yang akan diselenggarakan.

3) Melakukan survei kegiatan ini diakhiri dengan membuat kerjasama berupa pengagendaan jadwal kegiatan PKM.

4) Mendata dengan baik seluruh peserta kegiatan dan fasilitas yang dapat digunakan selama berkegiatan.

5) Merealisasikan seluruh agenda di atas secara tertulis dalam naskah proposal kegiatan PKM. Kemudian menyerahkannya kepada LPPM UPI YPTK Padang sesuai dengan arahan dan prosedur yang telah ditentukan.

Metode Pelaksanaan kegiatan pengabdian kepada masyarakat ini dilakukan dengan cara online dalam bentuk Webinar. Implementasi kegiatan dapat diuraikan pada gambar dibawah ini:

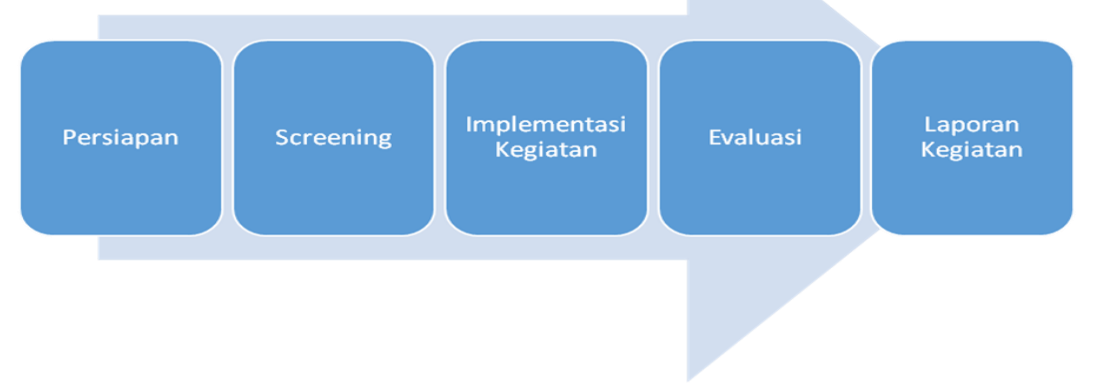

Gambar 1. Diagram Proses Implementasi Kegiatan

1) Persiapan

Persiapan dari kegiatan ini mencakup beberapa prosedur : menyiapkan materi, survei, mengurus surat-surat perizinan, membuat proposal dan proses persetujuan pengabdian kepada masyarakat. 


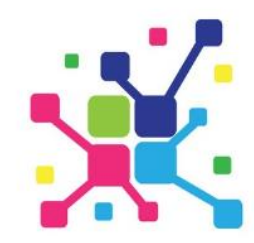

\section{2) Screening}

Setelah memaksimalkan persiapan, screening kemudian menjadi agenda selanjutnya. Ada beberapa tahap yang dilakukan : menyiapkan pembicara dan panitia sebelum acara, memastikan semua materi siap untuk disampaikan, memastikan semua kebutuhan acara seperti hadiah dan pamflet tersedia.

3) Implementasi Kegiatan

Sebelum acara dimulai pemateri memberikan angket dengan beberapa soal yang menanyakan pengetahuan tentang edit foto menjadi video dan edit video dengan aplikasi Kinemaster kepada para peserta yang merupakan tenaga pengajar di kota Padang. Lalu dilanjutkan tentang latar belakang diberlakukan social distancing, memberikan edukasi tentang peraturan pemerintah tentang mewajibkan belajar secara online. Selanjutnya mencari solusi dari masalah pembelajaran daring agar siswa atau mahasiswa lebih semangat dan termotivasi belajar secara online. Berikutnya pemaparan inti materi yaitu menjelaskan tentang cara mengedit foto menjadi video, cara mendapatkan gambar bergerak yang nanti digunakan untuk video ajar. Lalu mengedit gambar tersebut untuk dijadikan video ajar yang diharapkan mampu memberikan semangat dan motivasi yang baru kepada siswa dan mahasiswa. Terakhir pemberikan angket lagi kepada peserta untuk menanyakan pengetahuan peserta tentang edit foto menjadi video dan edit video dengan aplikasi Kinemaster setelah acara seminar pengabdian masyarakat selesai.

4) Evaluasi

Pada pengabdian masyarakat kali ini, evaluasi langsung diberikan diakhir sesi webinar. Peserta diminta untuk mengisi angket yang pertanyaaanya merupakan pengetahuan tentang edit foto menjadi video dan mengedit gambar bergerak menjadi video ajar.

5) Laporan dan Luaran Kegiatan

Laporan dan luaran kegiatan PKM disusun oleh tim PKM mandiri UPI YPTK Padang setelah kegiatan selesai dilaksanakan. Laporan kegiatan tersebut diserahkan kepada LPPM UPI YPTK Padang dan luarannya publish dijurnal nasional.

\section{b. Waktu Efektif Pelaksanaan Kegiatan}

Pelaksanaan kegiatan pengabdian kepada masyarakat tentang Pelatihan Membuat Video Pembelajaran Keren untuk Meningkatkan Pemahaman Siswa dan Mahasiswa dalam Masa Pandemi Covid-19 pada tanggal 20 Juni 2021 dengan waktu 5 jam.

\section{c. Tempat Kegiatan}

Pelaksanaan Kegiatan secara daring menggunakan aplikasi Zoom dan diikuti oeh Guru dan Dosen di Kota Padang. 
Hasil

Pada pengabdian kepada masyarakat ini setelah selesai acara inti webinar, kami meminta angket lagi. Hanya ada dua pertanyaan yang diajukan, tim Pengabdian kepada Masyarakat ingin mengevaluasi secara langsung materi yang disajikan, apakah peserta memperoleh ilmu dan mampu menggunakan teknologi baru dalam membuat video mengajar.

Pertanyataan 1 : Apakah anda telah mendapatkan pengetahuan baru mengenai aplikasi Kinemaster dari video tutorial yang kami berikan?

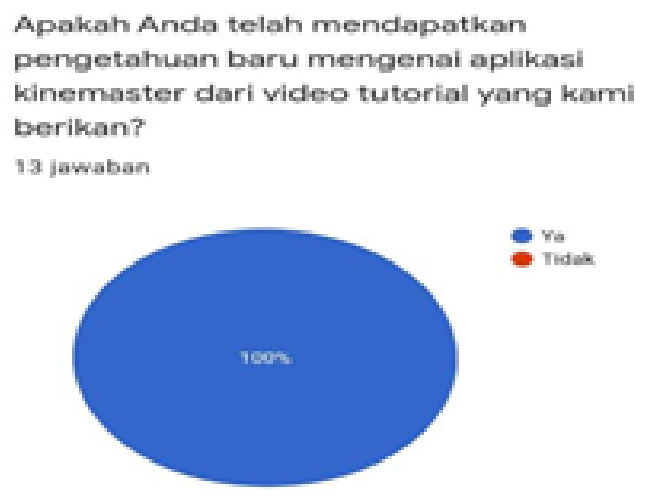

Gambar 2. Diagram hasil pertanyaan : “Apakah Anda telah mendapatkan pengetahuan baru mengenai aplikasi Kinemaster dari video tutorial yang Kami berikan?"

Dengan tanggapan positif dari para pengajar yang menjawab $100 \%$ mendapatkan pengetahuan baru mengenai aplikasi Kinemaster, kami Tim Pengabdian kepada Masyarakat UPI YPTK Padang berharap webinar yang kami adakan dapat di praktekkan dan para pengajar bisa membuat video pembelajaran animasi sebaik mungkin.

Pertanyaan 2 : Setelah mengikuti pelatihan ini, apakah anda sudah bisa membuat video pembelajaran mengunakan video animasi bergerak?

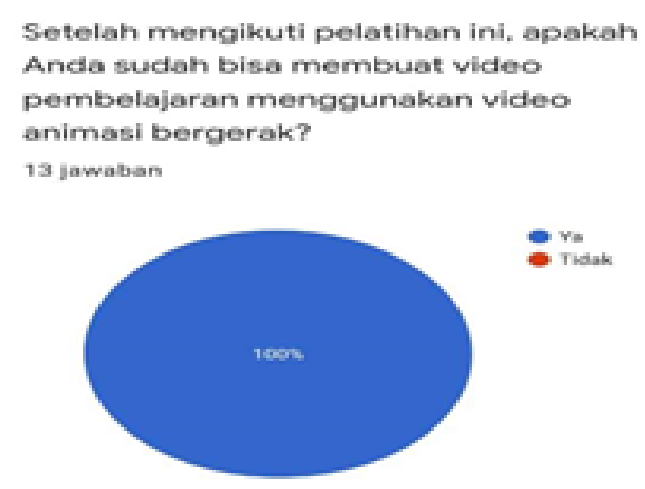

Gambar 3. Diagram hasil pertanyaan "Setelah mengikuti pelatihan ini, apakah Anda sudah bisa membuat video pembelajaran menggunakan video animasi bergerak?" 
Terlihat dari pernyataan 2 pada gambar 3 diatas bahwa webinar tentang Kinemaster ini memperoleh tanggapan yang baik dari para pengajar dosen atau guru. Pengajar 100\% menjawab mampu untuk membuat video pembelajaran menggunakan animasi bergerak. Dengan antusias dan semangat para peserta untuk membuat video pembelajaran yang menarik diharapkan peserta didik dapat paham dengan materi yang diberikan walaupun secara daring.

\section{Diskusi}

Diawal sesi sebelum dimulainya webinar Tim Pengabdian kepada Masyarakat menyebarkan kuesioner menggunakan google form kepada para peserta sehingga diperoleh bahwa dosen dan guru mengalami kendala dalam mengajar secara daring. Ini dapat dilihat dari grafik hasil kuesioner yang peserta isi. Ada 4 pertanyaan yang diberikan kepada peserta sebagai berikut [6] :

Pertanyaan 1 : Apakah anda mengalami kebingungan bagaimana cara mengajar siswa/mahasiswa secara daring?

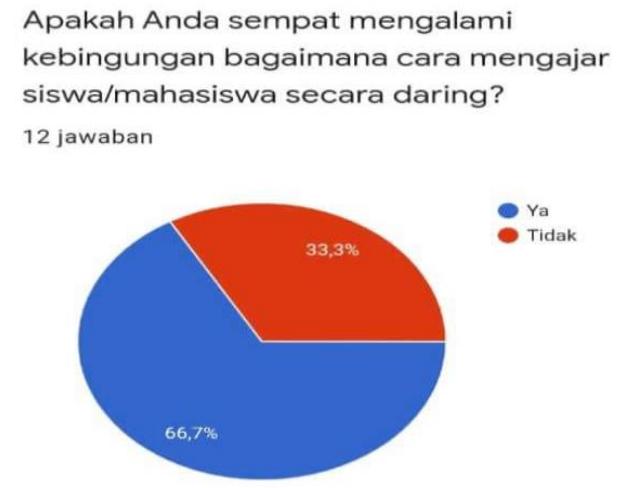

Gambar 4. Diagram hasil pertanyaan "Apakah anda mengalami kebingungan bagaimana cara mengajar siswa/mahasiswa secara daring?"

Dari pernyataan diatas dapat dilihat pada gambar 4 sebesar $66,7 \%$ masih binggung dalam melakukan pembelajaran secara daring, lebih dari separoh para pengajar mengalami kebingungan dalam melaksanakan pembelajaran secara daring ini. Kebingungan ini dapat berupa metoda ajar apa yang akan disajikan sehingga siswa atau mahasiswa mudah memahami dan tetap termotivasi pada materi yang diajarkan. 


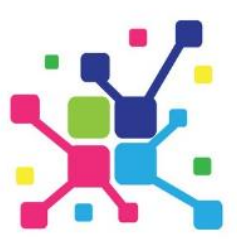

Pertanyaan 2 : Apakah anda bisa membuat video pembelajaran yang menarik?

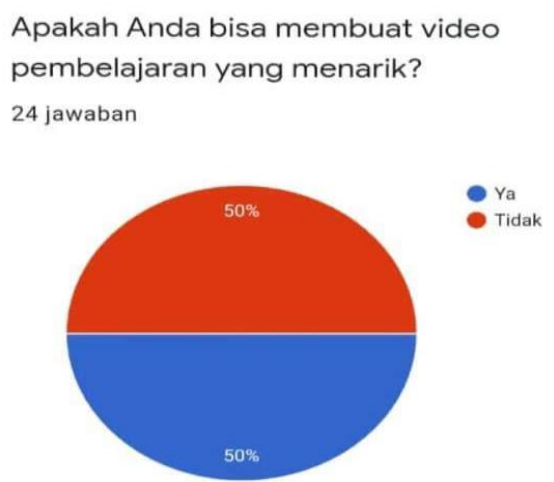

Gambar 5. Diagram hasil pertanyaan "Apakah Anda bisa membuat video pembelajaran yang menarik?"

Dilihat dari grafik pada gambar 5 diatas kita mengetahui bahwa $50 \%$ bisa membuat video pembelajaran yang menarik dan 50\% peserta lain tidak mampu membuat video pembelajaran yang menarik.

Pertanyaan 3 : Apakah Anda mengenal aplikasi Kinemaster?

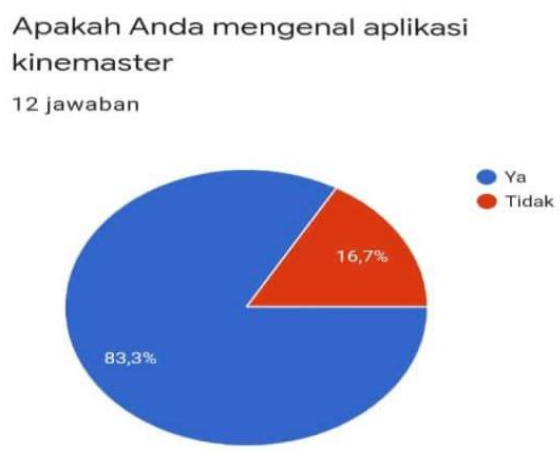

Gambar 6. Diagram hasil pertanyaan "Apakah Anda mengenal aplikasi Kinemaster?"

Aplikasi yang akan disajikan Tim Pengabdian kepada Masyarakat Kinemaster ini ternyata sudah familiar dikalangan para pengajar. Dilihat dari persentase pada gambar 6 diatas, terdapat 83,3\% para pengajar tahu tentang Kinemaster dan sisanya 16,7\% pengajar lain tidak mengenal Kinemaster. 


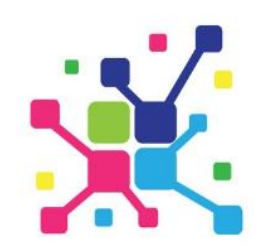

Pertanyataan 4 : Apakah Anda paham menggunakan aplikasi kinemaster?

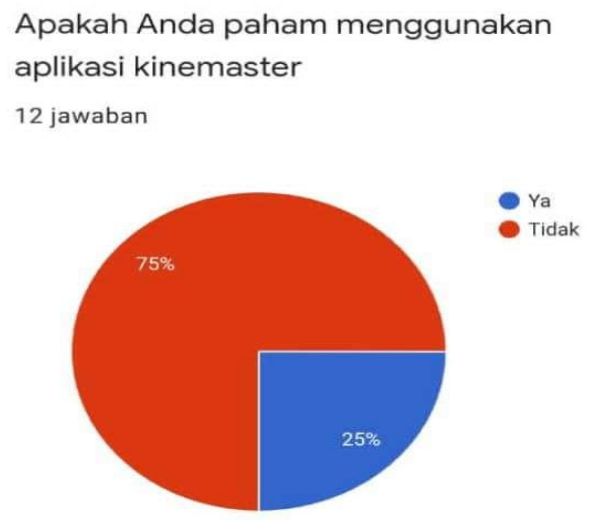

Gambar 7. Diagram hasil pertanyaan "Apakah Anda paham menggunakan aplikasi Kinemater?"

Walaupun para peserta merupakan pengajar pada Pengabdian kepada Masyarakat ini sudah familiar dengan Kinemaster tetapi masih banyak diantara para dosen dan guru yang belum bisa menggunakan aplikasi Kinemaster. Ini dapat dapat dilihat pada gambar 7 diatas.

\section{Kesimpulan}

Dengan diadakannya kegiatan Pengabdian kepada Masyarakat ini, maka telah dilaksanakan salah satu tridharma perguruan tinggi yaitu mengembangkan, mentransformasikan dan menyebarkan ilmu pengetahuan. Dari hasil pelaksanaan kegiatan Pengabdian kepada Masyarakat, maka dapat disimpulkan sebagai berikut : 1) Dapat meningkatkan pengetahuan para pengajar di kota Padang dalam menyajikan bahan ajar yang menarik, dan 2) Pengajar mampu membuat video pembelajaran menggunakan Kinemaster. Hal ini dibuktikan dari hasil survei evaluasi Pengabdian kepada Masyarakat yang memperlihatkan peserta 100\% menjawab mampu memahami materi dan membuat video pembelajaran yang menarik.

\section{Daftar Referensi}

[1] Septiyan, D. D. 2020. Perubahan Budaya Musik Di Tengah Pandemi Covid-19, Musikolastika: Jurnal Pertunjukan dan Pendidikan Musik. doi: 10.24036/musikolastika.v2i1.37.

[2] Yunus, N. R. and Rezki, A. 2020. Kebijakan Pemberlakuan Lock Down Sebagai Antisipasi Penyebaran Corona Virus Covid-19, SALAM: Jurnal Sosial dan Budaya Syar-i. doi: 10.15408/sjsbs.v7i3.15083. 
[3] Riadi, S., Normelani, E.N., Efendi, M., Safitri, I. and Tsabita, G.F.I., 2020. Persepsi Mahasiswa Prodi S1 Geografi FISIP ULM Terhadap Kuliah Online Di Masa Pandemi Covid-19. PADARINGAN (Jurnal Pendidikan Sosiologi Antropologi),2(2), pp.219227.

[4] Khairani, M., Sutisna, S. and Suyanto, S. 2019. Meta-analysis study of the effect of learning videos on student learning outcomes, Journal of Biological Education and Research, 2(1), p. 158.

[5] Endriani, D. et al. 2020. Tips dan Triks Mengajar Anak di Rumah selama Pembelajaran Online, Jurnal Laporan Abdimas Rumah Ilmiah, 1(1), pp. 55-61. Available at: http://www.jlari.org/index.php/jlari.

[6] Darmawan, G. et al. 2021 Pengaruh Covid-19. Edited by T. A. Marlin. Selayo, Sumatera Barat - Indonesia: Penerbit Insan Cendekia Mandiri. 